\title{
Teachers' Views on Course Supervision Competencies of Secondary School Managers"
}

\author{
Arslan Bayram \\ Department of Educational Sciences, Faculty of Education, Artvin Coruh University, Turkey
}

Copyright $\bigcirc 2016$ by authors, all rights reserved. Authors agree that this article remains permanently open access under the terms of the Creative Commons Attribution License 4.0 International License

\begin{abstract}
The definition of supervision in the dictionary is "to look after", "to direct," "to watch over," and "to check." It is usually seen as a tool to manage the teacher. Understanding of supervision in education has shown a change and progress in line with approaches and theories regarding management. The scanning model was used in this study, which aims to determine the course audit proficiency of the teachers and whether their course audit proficiencies show a significant difference according to various variables. The sample of this study consisted of 342 teachers in the 2015-2016 academic year in the province of Artvin. The opinions of the teachers were reflected based on sex, seniority and branch.
\end{abstract}

Keywords Educational Manager, Control, Course Supervision, Supervision Competencies

\section{Introduction}

The definition of supervision in the dictionary is "to look after", "to direct," "to watch over," and "to check." It is usually seen as a tool to manage the teacher. Escape of both new and experienced teachers from the education system partially stems from external control of teachers' professional lives ([15]; cited by: [3]).

Understanding of supervision in education has shown a change and development in line with the approach and theories regarding management. According to the principles, assumptions and approaches revealed by management theories, points of view regarding supervision are diverse [4]. Supervision, in the general sense, is the process of measuring the productivity of organizations which are in the public sector and have legal entity [27]. Supervision can be thought as the process of making sense of whether organizational activities are suitable to the principles and rules which were determined in accordance with the accepted purposes. The general aim of supervision is to determine the degree of fulfillment of the organization's purposes, take necessary precautions for better results and improve the process [4].
Supervisors are the main factors in reaching the desired goals in education and implementing inspectional elements towards improving human resources. Since supervisors may affect and assess the education system directly, they have significant roles in educational organizations [1].

There are quite close relations between supervision and leadership. In fact, a supervisor is a leader as a matter of course[27]. The function of supervision in schools is to bring together different factors of educational efficiency into the whole school mechanism. In other words, when teachers accept the shared purposes for students, they complete each other's education and supervisors work with teachers as consistently as teachers working with students, so the school purposes are met [3]. A manager who implements the management processes in schools also needs to make a process and result assessment in the evaluation process. In order to reach its purposes, the organization needs to make a process assessment regarding the educational progress. Of course, it can be actualized with lesson supervisions that will improve education.

According to the regulations of the Ministry of National Education published in the Official Journal on 17 April 2015, all teachers will be evaluated by school principals starting from the 2015-2016 academic year. In this case, in order for the manager to be able to make lesson supervision happen he/she needs to have some level of knowledge and adequacy of experience. The supervision which is done effectively will also lead to effectiveness in education activities. Effective supervision will require knowledge accumulation and interpersonal skills. These are implemented via technical supervisory duties that provide support directly to the teacher such as development of curriculum, career development, group development and action research, and cultural tasks such as those that facilitate the change, manage the differentiation and educate the society [3].

One of the most important subjects in supervision is to obtain the right information about the efficiency of the teacher. Well-trained supervisors know how to gather the right information; effective data gathering techniques mean much more than monitoring the seen and recorded [4].

One of the principle conditions for schools to train their 
students is management conducted well. The essential part of good management is supervision, because supervision is an important process. As it is the last of the management processes, supervision is the duty of the manager. If the organization is expanded too much or some jobs surpass the knowledge of the manager, the supervisors can be given roles to help the manager in supervisory tasks. Even in this situation, the manager should not leave the whole supervision duty to the supervisors. School principal must supervise everything about his/her school as well [8]; cited by:[28]).

Course audit is a type of supervision which aims to examine and evaluate the skillfulness of teachers among each other, the methods they use, the competency in using these and the levels of cultivation of the students. In the course audits, not only the academic hours but also how he/she practices the curriculum, the competency in his/her preparation of questions, the exams that he/she manages, the homework that he/she gives and the attention that he/she pays in correcting them, the level of knowledge and talent, the success in directing student towards personal studies, the activities which are in and out of the school are examined and evaluated [27].

The most important duties of the school principals are the education leadership [10] and evaluation of the staff [13]. As an education leader, the school manager must frequently observe the education in the class and join it [5]. In this context, school principals can supervise education by joining the class of the teacher informally at certain times. However, the purpose here is certainly not to catch the teacher unprepared or disrupt the class, the aim of these evaluations is to develop education [23]. As things stand, the aim of these short - term visits in the form of one full class or $10-15$ minutes of observations is to motivate the teachers for the class, monitor the education, determine some matters that need to be supported and be informed on education activities in the school [28].

It can be said that there is a common understanding between educators that there should be a supervision process in the education system as well ([4]; [6]; [10]; [19]; [26]; [27]). Today, supervision of education has become one of the important factors in making the school a more effective learning environment [24] and fulfilling the aims of the education system [10]. In order to directly affect schools' fulfilment of the fundamental educational purposes, supervision needs to follow the outcomes and efficiency of the schools closely and take precautions that will enable the constant increase[20].

Supervision of today is understood as updating managers and teachers on various levels who work in management and teaching with new information in their field, providing them with an effective service of guidance and satisfying the conditions of modern guidance, rather than as a point of view or approach which assesses whether the services provided comply with the laws and determined rules and analyzes the discipline of employees in this regards [25].

It is of great importance that the qualifications of the supervisors that carry out the supervision activity are at a high level and they perform their roles effectively. Supervisors have investigation duties as well as counselling, professional help and upbringing on-the-job [12].

In Turkey, some studies were carried out about supervision duties of school principals from the past to the $\operatorname{present}([9] ;[14] ;[15] ;[21] ;[22] ;[28])$. These studies aimed to reveal the existing situation of school principals' supervision duties.

In our country, course audit of teachers has been left to school principals. This scale prepared by benefiting from the articles in the "Teacher Evaluation Form" by the Ministry of National Education and Supervision Directorate will make a contribution to the literature. The research here was conducted with the aim of determining the lesson supervision competencies according to the opinions of the teachers.

\section{Methodology}

The scanning method was used in this study, which aimed to determine course audit proficiency of high school principals according to the opinions of the teachers and whether course audit proficiencies show a significant difference according to various variables. The scanning model is a study approach that aims to describe a situation which existed in the past or still exists, in the way that it exists [17]. With the aim of passing a judgment about the population, it is implemented on the entire population or a sample, so the results can be generalized into the population.

\subsection{Example}

In this study, the sample was taken from out of a target population of 3750 with the arbitrary sampling technique. The sample of this study consisted of 342 teachers who worked in the province of Artvin in the 2015-2016 academic years. Distribution of the teachers according to sex, seniority and branch is given at Table 1 . 
Table 1. Distribution of the Teachers According to Sex, Seniority and Branch

\begin{tabular}{|c|c|c|c|c|c|c|c|c|}
\hline Sex & Number & Percentage & Seniority & Number & Percentage & Branch & Number & Percentage \\
\hline Male & 98 & $28 \%$ & $1-10$ year & 47 & $13 \%$ & Language & 32 & $9 \%$ \\
\hline Female & 218 & $62 \%$ & $11-20$ year & 125 & $36 \%$ & Verbal & 115 & $33 \%$ \\
\hline Lost data & 35 & $10 \%$ & 21 year or more & 144 & $41 \%$ & Talent -Skill & 41 & $12 \%$ \\
\hline & & & Lost data & 35 & $10 \%$ & Numerical & 119 & $34 \%$ \\
\hline & & & & & & Lost data & 44 & $12 \%$ \\
\hline
\end{tabular}

According to Table 1, 28\% of the sample consisted of male teachers, while $62 \%$ were female teachers. $13 \%$ of the sample consisted of teachers who had 1-10 years of seniority, $36 \%$ of the sample consisted of teachers who had 11-20 years of seniority and $41 \%$ of the sample consisted of teachers who had 21 years or more seniority. $9 \%$ of the sample comprised language branch (English, French, German) teachers, while $33 \%, 12 \%$ and $34 \%$ comprised verbal branch (Geography, Literature, Philosophy, History), talent-skill (Visual Arts, Physical Education, Music) branch and numerical branch (Maths, Technology, Biology, Chemistry, Physics) teachers respectively.

\subsection{Data Collection Tool}

The Course Audit Qualifications Scale developed by the researcher based on "Course Audit Qualifications" by Ministry of National Education was used as the data collection tool. The data collection tool developed in the study comprised two categories. The first category consisted of three questions in which personal characteristics of the teachers were asked, while the second category comprised 24 articles that would enable determining the course audits of school principals according to the opinions of the teacher. They were the items which the principals and the auditors need to take into consideration in "Teacher Assessment Form". While the items in the "Teacher Assessment Form" that had indicators that need to be considered but the high school principals were included in the scale, the questions were changed into the characteristics that the school principals need to consider from the teacher's point of view, not as the behaviours that the teacher performs from the school principal's point of view. The scale consisted of the aspects of planning, classroom management and in-class activities. Five point Likert type was turned into a scale and the opinions of five experts were consulted.

\subsection{Study of Validity and Reliability}

Exploratory factor analysis was performed in order to determine how many dimensions the 24-item measurement developed by the researcher had. Pre-implementation was done with 200 teachers. At the end of the analysis, it was revealed that the scale was a one-dimensional scale that had 24 items. It was found that the KMO value was 0.91 , factor load values changed between 0.82 and 0.50 , and Cronbach Alpha factor was 0.95 . It was revealed that the total correlations of corrected material changed between 0.47 and 0.79 .

\subsection{Data analysis}

Arithmetic means of the data were determined in order to detect the course audit qualifications of high school principals according to the opinions of the teachers. T-test and variance analyses were done in the inspection of the opinions of the teachers regarding the course audit qualifications according to sex, seniority and branch.

\section{Results}

Arithmetic mean and standard deviation values regarding the course audit qualifications of the high school principals according to the teachers are given in Table 2 . 
Table 2. According to the opinions of the teachers, arithmetic mean and standard deviation values regarding the course audit qualifications

\begin{tabular}{|c|c|c|c|}
\hline $\begin{array}{l}\text { Article } \\
\text { No. }\end{array}$ & Article & $\begin{array}{l}\text { Arithmetic } \\
\text { Mean }\end{array}$ & $\begin{array}{l}\text { Standard } \\
\text { Deviation } \\
\end{array}$ \\
\hline 1 & It supervises My Reflection of Field, Program and Content Information into Education & 2.78 & 1.25 \\
\hline 2 & It supervises Daily/Course Preparation and Application Performance with Unitized Annual Plans. & 3.22 & 1.19 \\
\hline 3 & It supervises the preparation and application of class plans in the way that they are wished. & 3.40 & 1.18 \\
\hline 4 & It supervises my Collaboration with Class Mates. & 3.52 & 1.20 \\
\hline 5 & It supervises my authority, motivating students for the course. & 3.28 & 1.22 \\
\hline 6 & It supervises my choice and application of the education method. & 3.02 & 1.20 \\
\hline 7 & $\begin{array}{l}\text { It supervises my evaluation of the time in teaching a class and achievement of usage of the course } \\
\text { book. }\end{array}$ & 3.37 & 1.21 \\
\hline 8 & It supervises my achievement in using the course equipment effectively. & 3.28 & 1.16 \\
\hline 9 & $\begin{array}{l}\text { It supervises my achievement in using technological equipment (projection, computer, smart board } \\
\text { etc.). }\end{array}$ & 3.37 & 1.13 \\
\hline 10 & $\begin{array}{l}\text { It supervises the update of units and theme columns in accordance with the subjects which are } \\
\text { taught. }\end{array}$ & 3.15 & 1.14 \\
\hline 11 & It supervises my direction in the homeworks given to the students. & 2.91 & 1.20 \\
\hline 12 & It supervises my supply of each student with appropriate opportunities in in-class activities. & 3.03 & 1.20 \\
\hline 13 & $\begin{array}{l}\text { It supervises students' interest and participation in the course, courage and success in asking and } \\
\text { answering questions }\end{array}$ & 3.11 & 1.14 \\
\hline 14 & It supervises the precautions that I have taken in order to increase the success of the students. & 3.14 & 1.09 \\
\hline 15 & It supervises my formation/arrangement/update of a class library. & 2.99 & 1.12 \\
\hline 16 & It supervises my contribution to the general functioning of the school. & 3.49 & 1.03 \\
\hline 17 & It supervises my planning/implementation/saturation of free time activities. & 3.23 & 1.11 \\
\hline 18 & It supervises me being given the project and the performance assessment and evaluation. & 3.26 & 1.11 \\
\hline 19 & It supervises my adaptation to the factors to be paid attention to in teaching a class. & 3.23 & 1.20 \\
\hline 20 & It supervises my usage of the e-okul module/update on student information. & 3.50 & 1.11 \\
\hline 21 & $\begin{array}{l}\text { It supervises my adaptation to the basics of cooperation with parents of the students/arranging } \\
\text { parent-teacher meetings. }\end{array}$ & 3.56 & 1.14 \\
\hline 22 & $\begin{array}{l}\text { It supervises my general state and behaviour, my state and behaviour towards colleagues and } \\
\text { superiors. It supervises my usage of student course books in accordance with their purpose. }\end{array}$ & 3.54 & 1.09 \\
\hline 23 & It supervises my preparation and implementation of plans for the inclusive program students. & 3.61 & 1.22 \\
\hline 24 & $\begin{array}{l}\text { It supervises my announcement of exam dates in advance, preparation of answer key, scoring in } \\
\text { accordance with the key. }\end{array}$ & 3.85 & 1.19 \\
\hline
\end{tabular}

According to Table 2, the items that showed the highest participation regarding the course audit qualifications of the high school principals according to the opinions of the teachers can be listed from high to low as item 24 (It supervises my announcement of exam dates in advance, preparation of answer key, scoring in accordance with the key $-\mathrm{x}=3.85$ ), item 23 (It supervises my preparation and implementation of plans for the inclusive program students $\mathrm{x}=3.61$ ) and item 22 (It supervises my general state and behaviour, my state and behaviour towards colleagues and superiors. It supervises my usage of student course books in accordance with their purpose - $\mathrm{x}=3.54$ ). The articles in which the teachers showed the least participation regarding the course audit qualifications can be listed from high to low as item 15 (It supervises my formation/arrangement/update of a class library - $\mathrm{x}=2.99$ ), item 11 (It supervises my direction in the homework given to the students $-\mathrm{x}=2.91$ ) and item 1 (It supervises My Reflection of Field, Program and Content Information to Education $-\mathrm{x}=2.78$ ).
The results of the t-test according to sex regarding course audit qualifications of high school principals in accordance with the opinions of the teachers.

Table 3. $\mathrm{T}$ - test results of the high school principals according to the opinions of the teachers based on sex

\begin{tabular}{|c|c|c|c|c|c|c|}
\hline Groups & $\mathrm{N}$ & $\mathrm{X}$ & $\mathrm{SS}$ & $\mathrm{sd}$ & $\mathrm{t}$ & $\mathrm{p}$ \\
\hline Male & 98 & 3.25 & 0.80 & \multirow{2}{*}{314} & -0.61 & 0.53 \\
\hline Female & 218 & 3.31 & 0.80 & & & \\
\hline
\end{tabular}

According to Table 3, course audit qualifications of the high school principals did not show a significant difference according to the sex of the teachers $[t=-0.61, p>0.05]$.

According to the opinions of the teachers, one way analysis of variance results of the course audit qualifications of the high school principals in accordance with seniority are given in Table 4. 
Table 4. According to the opinions of the teachers, one way analysis of variance results of the course audit qualifications of the high school principals in accordance with seniority

\begin{tabular}{|c|c|c|c|c|c|c|}
\hline $\begin{array}{c}\text { The } \\
\text { source } \\
\text { of the } \\
\text { variance }\end{array}$ & $\begin{array}{c}\text { Sum of } \\
\text { squares }\end{array}$ & sd & $\begin{array}{c}\text { Mean } \\
\text { of } \\
\text { squares }\end{array}$ & $\mathrm{F}$ & $\mathrm{p}$ & $\begin{array}{c}\text { Significant } \\
\text { difference }\end{array}$ \\
\cline { 1 - 5 } $\begin{array}{c}\text { In } \\
\text { between } \\
\text { groups }\end{array}$ & 1.31 & 2 & 0.65 & \multirow{2}{*}{1.00} & 0.36 & - \\
\cline { 1 - 3 } $\begin{array}{c}\text { Inter } \\
\text { groups }\end{array}$ & 204.58 & 313 & 0.65 & & & \\
\cline { 1 - 3 } Total & 205.90 & 315 & & \\
\hline
\end{tabular}

According to Table 4, course audit qualifications of the high school principals in accordance with the opinions of the teachers did not show a significant difference $[F=1.00$, $\mathrm{p}>0.05]$.

One way analysis of variance results of the high school principals' course audit qualifications in line with the branch according to the opinions of the teachers are given in Table 5.

Table 5. One way analysis of variance results of the high school principals' course audit qualifications in line with the branch according to the opinions of the teachers

\begin{tabular}{|c|c|c|c|c|c|c|}
\hline $\begin{array}{c}\text { Source of } \\
\text { the variance }\end{array}$ & $\begin{array}{l}\text { Sum of } \\
\text { squares }\end{array}$ & sd & $\begin{array}{c}\text { Mean } \\
\text { of } \\
\text { squares }\end{array}$ & $\mathrm{F}$ & $\mathrm{p}$ & $\begin{array}{l}\text { Significant } \\
\text { difference }\end{array}$ \\
\hline $\begin{array}{c}\text { In between } \\
\text { groups }\end{array}$ & 1.92 & 3 & \multirow[t]{2}{*}{0.64} & \multirow{3}{*}{0.98} & \multirow{3}{*}{0.39} & \multirow{3}{*}{ 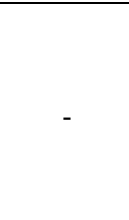 } \\
\hline Inter-groups & 196.50 & 303 & & & & \\
\hline Total & 198.42 & 306 & 0.64 & & & \\
\hline
\end{tabular}

According to Table 5, course audit qualifications of the high school principals did not show a significant difference based on the branches of the teachers $(F=0.98, p>0.05]$.

\section{Conclusion and Recommendations}

This study, which aims to determine the opinions of the teachers about course audits of the school principals who work at high schools, reveals conclusions such as the following:

* the opinions of the teachers regarding the sub-dimensions of the teachers' opinions scale about the course audits of the high school principals were found "positive" in three dimensions. Firıncıoğulları [16] also reached similar results in the study called Opinions of Teachers on Course Audits of the Elementary School Principals.

* Opinions of the teachers about the course audits of high school principals did not result in a significant difference according to their seniority in the profession Firıncioğulları [16] in the study titled Opinions of Teachers on Course Audits of the Elementary School Principals, and Ağaoğlu, Altınkurt, Yılmaz and Karaköse [2] in the study titled Opinions of School Managers and Teachers Regarding the
Efficiency of the School Managers, reported that the opinions of teachers who had 1-5 years of seniority showed a difference, while the opinions of the remaining teachers seniority showed similarity.

* In the opinions of the teachers on the course audits of the high school principals, a significant difference was not found according to the sexes of the teachers. Similar results were reached in the study titled the Opinions of Teachers about the Course Audits of the Elementary School Principals [16].

* There was no significant difference in the opinions of the teachers about the course audits of high school principals according to the branches of the teachers. Similar results have been found in the study titled opinions of Teachers on the Course Audits of the Elementary School Principals [16].

The issue of how reliably school principals will conduct class supervision is a subject of ongoing debate. There are studies suggesting that school principals, who work side by side with teachers in the same environment, will not be able to conduct supervision impartially. Although the results of this study found that school principals had supervision skills, there are still problems in impartial supervision due to the problems in the school principal appointment system. The study by Altun, Şanlı and Tan [25] also revealed this situation.

Balyer [7] stated regarding the role expectations from school principals that, principals are expected to show behaviors different from those in the past, but studies on the roles of school principals reported that the changes in such roles take place mostly in areas such as establishment of authority, responsibility, improvement of teaching curriculum and implementations, financial issues, personnel evaluation, establishing policies regarding the school and participation in decision-making.

School principals should participate in in-service training programs in order to improve their supervisory capabilities. It may also be recommended that they take graduate level academic training on education management and supervision. School principals should be educational leaders to be able to perform their supervision duties effectively.

\section{Note}

*The abstract of this paper was presented at 2nd International Conference on Lifelong Learning and Leadership for All (ICLEL-16), in Liepaja on July, 21-23, 2016.

\section{REFERENCES}

[1] Aküzüm, C. ve Özmen, F. (2013). Eğitim denetmenlerinin rollerini gerçekleştirme yeterlikleri bir meta-sentez çalışması. EKEV Akademi Dergisi, 17(56), 97-120

[2] Ağaoğlu, E., Altınkurt, Y., Yılmaz, K.,Karaköse, T. (2012). Okul yöneticilerinin yeterliklerine ilişsin okul yöneticilerinin 
ve öğretmenlerin görüşleri (Kütahya İli). Education and Science. 2012, Vol. 37, No 164.

[3] Aksu, M., Ağaoğlu, E. (2014). Denetim ve Öğretimsel Liderlik. Anı Yayıncilık. Ankara.

[4] Aydın, İ. (2005).Öğretimde Denetim. PegemA Yayıncılık. Ankara.

[5] Balc1, A. (2005). Eğitim yönetimi terimleri sözlügüü. Ankara: Tek Ağaç Yayıncılık.

[6] Balcı, A., Aydın, İ., Yılmaz, K., Memduhoğlu, H. B. ve Apaydın Ç. (2007). Türk eğitim sisteminde ilköğretimin yönetimi ve denetimi: Mevcut durum ve yeni perspektifler. S. Özdemir, H. Bacanlı, ve M. Sözer (Ed.). Türkiye'de okul öncesi eğitim ve ilköğretim sistemi temel sorunlar ve çözüm önerileri içinde (s. 126-185). Ankara: Türk Eğitim Derneği Yayınları.

[7] Balyer, A. (2012). Transformational leadership behaviors of school principals: A qualitative research based on teachers' perceptions. International Online Journal of Educational Sciences, 4(3), 581-591

[8] Basar, H. (1988). Öğretmenlerin değerlendirilmesi. Ankara: Pegem Yayıncılık.

[9] Başar, H. (1981). Okul Yöneticisinin Denetim Görevi. (Yayınlanmamış yüksek lisans tezi) Ankara: Ankara Üniversitesi Eğitim Fakültesi.

[10] Başar, H. (2000). Eğitim denetçisi. Ankara: Pegem A Yayıncilik

[11] Bursalığlu, Z. (1980). Eğitim yöneticisinin davranış etkenleri. Ankara: Ankara Üniversitesi Eğitim Fakültesi Yayını.

[12] Ceylan, M. ve Ağaoğlu, E. (2010). Eğitim denetçilerinin danışmanlık rolü ve danışmanlık modelleri. İlköğretim Online Dergisi, 9 (2), 541-551.

[13] Dönmez, B. (2002). Müfettiș, okul müdürü ve öğretmen algılarına göre ilköğretim okulu müdürlerinin yeterlikleri. Kuram ve Uygulamada Eğitim Yönetimi, 8 (29), 27-45.

[14] Dumrul, N. S. (1986). Đlkokul Müdürlerinin Denetim Yetki ve Yeterlikleri. (Yayınlanmamış yüksek lisans tezi) Ankara: Ankara Üniversitesi Sosyal Bilimler Enstitüsü.

[15] Ekleme, Y. (2001). İlköğretim okulu yöneticilerinin denetim ile ilgili görevlerini yerine getirme düzeyleri. Yayınlanmamış yüksek lisans tezi, Yıldız Teknik Üniversitesi, İstanbul

[16] Fırıncıoğulları, E. (2014). İlkokul Müdürlerinin Ders
Denetimleri ile İlgili Öğretmen Görüşleri. Adnan Menderes Üniversitesi, Sosyal Bilimler Enstitüsü. Yayımlanmamış Yüksek Lisans Tezi. Aydın.

[17] Karasar, N.(2015) Bilimsel Araştırma Yöntemi. Nobel Yayın Dağıtım. Ankara.

[18] Lavie, J. M. (2006). Academic discourses on school-based teacher collaboration: Revisiting the arguments. Educational Administration Quarterly,42, 773-805.

[19] Memduhoğlu H. B. ve Zengin M. (2010, Haziran). Çağdaş eğitim denetimi modeli olarak öğretimsel denetimin Türk eğitim sisteminde uygulanabilirliği. 2.Uluslararası Katılımlı Eğitim Denetimi Kongresinde sunulan bildiri. TemSen Yayınları, Kütahya.

[20] Memduhoğlu H. B. (2012). Öğretmen, Yönetici, Denetmen ve Öğretim Üyelerinin Görüşlerine Göre Türkiye'de Eğitim Denetimi Sorunsalı. Kuram ve Uygulamada Eğitim Bilimleri Educational Sciences: Theory \& Practice - 12(1) K1ş/Winter $135-156$

[21] Özdemir, İ. E. (1985) "Gazi Eğitim Fakültesi Öğrencilerinin Problemleri”, Hacettepe Üniversitesi, Psikolojik Hizmetler Ana -Bilim Dalı, (Basılmamış yüksek Lisans Tezi.)

[22] Özmen, F. ve Batmaz, C. (2006).İlköğretim okul müdürlerinin öğretmen deneti-mindeki etkililikleri, hizmet yılı ve görev türü değişkenine göre öğretmen görüşleri. Gaziosmanpaşa Üniversitesi Sosyal Bilimler Araştırmaları Dergisi,2, 102-120.

[23] Peterson, K. D. (1995). Teacher evaluation. Thousand Oaks, CA: Corwin Press, Inc. Sağlamer, E. (1985). Eğitimde teftis ve teknikleri. Ankara: Kadığlu Matbaası.

[24] Sergiovanni, T. J., \& Starratt, R. J. (1993). Supervision: A redefinition (7th ed.). NY: Mc Graw Hill.

[25] Şanlı, Ö., Altun, M., Tan, Ç. (2015). Öğretmenlerin akıllı tahta ve ögrencilere dağıtılan tablet bilgisayarlar ile ilgili yaşadıkları sorunlar ve çözüm önerileri. Turkish Studies International Periodical for the Languages, Literature and History of Turkish or Turkic, 10(3), 833-850.

[26] Süngü, H. (2005). Fransa, İngiltere ve Almanya eğitim denetimi sisteminin yapı ve işleyişi. Milli Eğitim Dergisi, 33 (167), 394-414.

[27] Taymaz, H.(2002). Eğitim Sisteminde Teftiş Kavramlar, Ilkeler, Yöntemler. Ankara: Pegem Yayıncılık

[28] Yılmaz, K. (2009). Okul Müdürlerinin Denetim Görevi. İnönü Üniversitesi Eğitim Fakültesi Dergisi. Cilt. 10, Sayı. 1 